\title{
The use of reactors in biomining processes
}

\author{
Fernando Acevedo \\ Escuela de Ingeniería Bioquímica \\ Universidad Católica de Valparaíso \\ Avenida Brasil 2147, Valparaíso, Chile \\ Tel: $56-32-273644$ \\ Fax: 56-32-273803 \\ E-mail: facevedo@ucv.cl
}

Financial support: FONDECYT Grants 1980338 and 1000284 UCV Projects 203.703/98 and 203.715/00.

Keywords: bacterial leaching, bioleaching, biooxidation, bioreactors, stirred tanks, Thiobacillus

Microbial processes applied to mining operations are gaining increasing interest in the last years. Potential and current applications include the mining of gold, copper and other heavy metals, desulfurization of coal and oil, tertiary recovery of oil and biosorption of metal ions. Currently, bacterial leaching of copper and biooxidation of refractory gold concentrates are wellestablished large-scale processes that are carried on using heaps and tank reactors. Heap operation is simple and adequate to handle large volumes of minerals, but their productivity and yields are limited because of the severe difficulties in exerting an adequate process control. On the other hand, reactors can economically handle moderate volumes of material, but they allow for a close control of the variables involved, rendering significantly better performances. This paper reviews the basis of reactor selection and design for bioleaching processes. Special attention is given to the influence of oxygen and carbon dioxide mass transfer, process stoichiometry, solids suspension and slurry homogeneity, and the use of bioreactors in gold mining. It is concluded that the future of reactors in biomining is promising and that new applications, such as the bioleaching of copper concentrates, will soon be a reality.

Microbial processes are gaining increasing interest in the mining industry. Bioleaching of heavy metals, biooxidation of gold ores, desulfurization of coal and oil, tertiary recovery of oil and biosorption of metal ions are examples of the wide variety of potential and actual applications of microorganisms in mining and related fields (Karavaiko, 1985; Kelley and Tuovinen, 1988; Lawrence and Poulin, 1995; Rawlings, 1997; Brierley and Brierley, 1999). Currently, bacterial leaching and biooxidation are largescale processes that are being successfully used in copper and gold processing (Acevedo et al. 1993; Brierley, 1997).

The term biomining have been coined to refer to the use of microorganisms in mining processes. Biomining encompasses two related microbial processes that are useful in the extractive metallurgy of heavy metals: bacterial leaching, also known as bioleaching, and biooxidation. Leaching is the solubilization of one or more components of a complex solid by contact with a liquid phase. In bacterial leaching, the solubilization is mediated by bacteria. So bacterial leaching is a process by which the metal of interest is extracted from the ore by bacterial action, as in the case of bacterial leaching of copper. On the other hand, biooxidation implies the bacterial oxidation of reduced sulfur species accompanying the metal of interest, as in the biooxidation of refractory gold minerals.

For many years bioleaching was thought as a technology for the recovery of metals from low-grade ores, flotation tailings or waste material (Torma, 1977; Gentina and Acevedo, 1985). Today bioleaching is being applied as the main process in large-scale operations in copper mining and as an important pretreatment stage in the processing of refractory gold ores.

The main advantages of bacterial leaching of copper and other heavy metals as compared with pyrometallurgy lie in its relative simplicity, mild operation conditions, low capital costs, low energy input, and in its friendliness towards the environment. The biooxidation of refractory gold ores presents similar characteristics when compared with roasting and pressure oxidation (Gentina and Acevedo, 1985; Acharya, 1990).

Bacterial leaching of copper is usually performed in heaps of ground ore or in dumps of waste or spent material. Heaps and dumps are irrigated in closed circuit with an acidic liquor that contains a fraction of the bacterial population, the rest being attached to mineral. When the desired metal concentration is attained, the rich liquor is pumped to the solvent extraction (SE) section and then sent to electrowinning $(\mathrm{EW})$, where the fine metal is recovered. The raffinate from the SE section is recycled to the heap or dump and the spent liquor of the EW section is recycled to the SE operation (Montealegre et al. 1993; Avendaño and Domic, 1994; Readett, 1999). 
Heaps and dumps present a number of advantages such as simple equipment and operation, low investment and operation costs and acceptable yields. On the other hand it must be realized that the operation suffers from some severe limitations: the piled material is very heterogeneous and practically no close process control can be exerted, except for intermittent $\mathrm{pH}$ adjustment and the addition of some nutrients. Moreover, the rates of oxygen and carbon dioxide transfer that can be obtained are low, and extended periods of operation are required in order to achieve sufficient conversions (Acevedo and Gentina, 1989).

From a process engineering standpoint, the complex network of biochemical reactions encompassed in bioleaching would best be performed in reactors. The use of reactors would allow a good control of the pertinent variables, resulting in a better performance. Parameters such as volumetric productivity and degree of extraction can be significantly increased (Pinches et al. 1988; Acevedo and Gentina, 1989; Gormely and Brannion, 1989; Adamov et al. 1990). The main limitation in the use of reactors in biomining is the very large amounts of run-of-mine ore that in most cases is to be treated. The Chuquicamata copper mine in Chile produced 630,000 tons of fine copper in 1999. The production of that amount of metal implied the treatment of around 6 million tons of run-of-mine. If such amount would to be treated in bioreactors, the required equipment volume would of the order of 30 million cubic meters, an unthinkable figure. This limits their application to the treatment of mineral concentrates or when moderate volumes of ore are to be processed. For instance, over 11,000 tons of gold concentrates are biooxidized in reactors every year.

The discussion that follows will center on the use of bioreactors in biomining, with emphasis in oxygen and carbon dioxide transfer, the maintenance of an adequate solids suspensions and the application of bioreactors to commercial mining operations.

\section{Reactors in bioleaching}

The selection of a suitable reactor for a biomining process and its design should be based in the physical, chemical and biological characteristics of the system. Adequate attention should be paid to the complex nature of the reacting sludge, composed by an aqueous liquid, suspended and attached cells, suspended solids, and air bubbles (Gormely and Brannion, 1989). Because of the very large volumes of material to be processed, bioleaching and biooxidation are best performed in a continuous mode of operation in which volumetric productivity is high and reactor volumes can be kept low. Considering the kinetic characteristics of microbial growth, a continuous stirred tank reactor, CSTR, appears as the first choice.

An important consideration in selecting a suitable reactor refers to the autocatalytic nature of microbial growth. This fact is common to all fermentation operations, but in bioleaching there is an important difference. In industrial fermentations the nutrients are chosen by their high affinity with the microbial population, while in biomining the mineral species involved are usually recalcitrant to microbial action, implying that the affinity is quite low. The substratemicroorganism affinity is related to Monod's saturation constant, $\mathrm{K}_{\mathrm{S}}$ (Monod, 1949). High affinities are reflected in low $\mathrm{K}_{\mathrm{S}}$ values, of the order of a few milligrams per liter, as in the case of most sugars. Some minerals have saturation constants as high as 3 to $6 \mathrm{~g} / \mathrm{L}$, that is, thousands of orders of magnitude higher. This situation affects the selection of the reactor. If a high degree of conversion is desired, a single agitated tank will require a very large volume, so an arrangement of reactors will be more suitable (Dew, 1995). It can be shown that a CSTR followed by a tubular plug flow reactor, PFR, gives the minimum reaction volume to attain a certain conversion (Levenspiel, 1972). Because the need of aeration and the presence of solid particles makes PFRs unpractical, their performance can be approximated by a series of CSTRs (González et al. 1999).

Other types of reactors that have been studied for their application in biomining are the percolation column, the Pachuca tank, the air-lift column, and some special designs such as rotary reactors (Atkins and Pooley, 1983; Atkins et al. 1986; Nikolov et al. 1986; Acevedo et al. 1988; Barrette and Couillard, 1993; Loi et al. 1995; Herrera et al. 1997; Acevedo et al. 1999; Canales et al. 1999; Nedeltchev et al. 1999; Rossi, 1999).

\section{Gas mass transfer}

Several mass transfer operations occur in a biomining operation. Nutrients have to reach the attached and suspended cells, metabolic products have to migrate from the cells to the liquid and solubilized species must be transported from the surface of the mineral particles to the liquid. In addition, two other important transport processes are to be considered: the supply of oxygen and carbon dioxide from the air to the cells. Carbon dioxide is demanded by the cell population as carbon source, while oxygen is needed as the final electron acceptor of the overall oxidation process. In reactors these gases are usually supplied by bubbling air into the liquid. In order to be used by the cells, oxygen and 
carbon dioxide must dissolve in the liquid, a mass transfer operation that presents a high resistance and can become limiting for the overall process rate.

A gas mass balance around the bioreactor gives (Wang and Humphrey, 1968):

$$
\frac{\mathrm{dC}_{\mathrm{Li}}}{\mathrm{dt}}=\mathrm{k}_{\mathrm{L}} \mathrm{a}_{\mathrm{i}}\left(\mathrm{C}_{\mathrm{i}}^{*}-\mathrm{C}_{\mathrm{Li}}\right)-\mathrm{N}_{\mathrm{i}}
$$

where $\mathrm{i}$ stands for oxygen or carbon dioxide, $\mathrm{N}$ is the gas demand $(\mathrm{g} g a s / l \cdot h), \mathrm{k}_{\mathrm{L}} \mathrm{a}_{\mathrm{i}}$ is the volumetric gas transfer coefficient $\left(\mathrm{h}^{-1}\right), \mathrm{C}_{\mathrm{i}}^{*}$ is the gas equilibrium concentration $(\mathrm{g} / \mathrm{L}), \mathrm{C}_{\mathrm{Li}}$ is the dissolved gas concentration, and $\mathrm{t}$ is time $(\mathrm{h})$.

The gas supply, $\mathrm{k}_{\mathrm{L}} \mathrm{a}_{\mathrm{i}}\left(\mathrm{C}_{\mathrm{i}}^{*}-\mathrm{C}_{\mathrm{Li}}\right)$, must equal the gas demand in order to avoid growth limitation, so

$$
\mathrm{N}_{\mathrm{i}}=\mathrm{k}_{\mathrm{L}} \mathrm{a}_{\mathrm{i}}\left(\mathrm{C}_{\mathrm{i}}^{*}-\mathrm{C}_{\mathrm{Li}}\right)
$$

The gas demands can be calculated as

$$
\mathrm{N}_{\mathrm{i}}=\frac{\mu \mathrm{X}}{\mathrm{Y}_{\mathrm{i}}}
$$

where $\mu$ is the specific growth rate of the cells $\left(\mathrm{h}^{-1}\right), \mathrm{X}$ is cell mass concentration $(\mathrm{g} / \mathrm{L})$, and $\mathrm{Y}_{i}$ is the gas cell yield (g cells/g gas).

The bioleaching process can be represented by a stoichiometric equation (Acevedo, 1987; Acevedo and Gentina, 1989). In the case of a leaching organism such as Thiobacillus ferrooxidans growing in a simple defined culture media with ferrous iron as the energy source, the following equation can be written:

$$
\begin{aligned}
& 1 \cdot \mathrm{CO}_{2}+\mathrm{m} \cdot \mathrm{NH}_{3}+\mathrm{n} \cdot \mathrm{FeSO}_{4}+\mathrm{o} \cdot \mathrm{H}_{2} \mathrm{SO}_{4}+\mathrm{p} \\
& \cdot \mathrm{O}_{2} \rightarrow \mathrm{C}_{5} \mathrm{H}_{7} \mathrm{O}_{2} \mathrm{~N}+\mathrm{r} \cdot \mathrm{Fe}_{2}(\mathrm{SO})_{3}+\mathrm{s} \cdot \mathrm{H}_{2} \mathrm{O}
\end{aligned}
$$

$\mathrm{C}_{5} \mathrm{H}_{7} \mathrm{O}_{2} \mathrm{~N}$ represents the biomass with an elemental composition of $53.1 \% \mathrm{C}, 6.2 \% \mathrm{H}, 28.3 \% \mathrm{O}$, and $12.4 \%$ $\mathrm{N}$ (Jensen and Webb, 1995). Elemental mass balances on $\mathrm{C}, \mathrm{H}, \mathrm{O}$ and $\mathrm{N}$, together with the experimental value of the ferrous ion cell yield of $0.0086 \mathrm{~g}$ cells $/ \mathrm{g} \mathrm{Fe}^{2+}$, allows for the calculation of the stoichiometric coefficients:

$5.0 \mathrm{CO}_{2}+\mathrm{NH}_{3}+241.37 \mathrm{FeSO}_{4}+120.67 \mathrm{H}_{2} \mathrm{SO}_{4}$ $+55.34 \mathrm{O}_{2} \rightarrow \mathrm{C}_{5} \mathrm{H}_{7} \mathrm{O}_{2} \mathrm{~N}+120.67 \mathrm{Fe}_{2}\left(\mathrm{SO}_{4}\right)_{3}+$ $118.67 \mathrm{H}_{2} \mathrm{O}$
The oxygen and carbon dioxide cell yields can be calculated from equation [5]:

$\mathrm{Y}_{\mathrm{O}_{2}}=\frac{1 \cdot \mathrm{M}_{\mathrm{c}}}{55.34 \cdot \mathrm{M}_{\mathrm{O}_{2}}}=0.064 \mathrm{~g}$ cells $/ \mathrm{g}$ consumed oxygen

$\mathrm{Y}_{\mathrm{CO}_{2}}=\frac{1 \cdot \mathrm{M}_{\mathrm{c}}}{5.0 \cdot \mathrm{M}_{\mathrm{CO}_{2}}}=0.51 \mathrm{~g}$ cells $/ \mathrm{g}$ consumed carbon dioxide

in which $\mathrm{M}_{\mathrm{c}}, \mathrm{M}_{\mathrm{O} 2} \mathrm{M}_{\mathrm{CO} 2}$ are the molecular masses of the cells, oxygen and carbon dioxide, respectively.

In an actual bioleaching operation, a similar stoichiometric representation can be made. For instance, for the biooxidation of enargite $\left(\mathrm{Cu}_{3} \mathrm{AsS}_{4}\right)$ from a refractory gold concentrate the following equation applies, considering an experimental value of $0.6 \mathrm{~g}$ cell/g Cu (Garcia, 1997):

$$
\begin{aligned}
& 5.0 \mathrm{CO}_{2}+\mathrm{NH}_{3}+\mathrm{Cu}_{3} \mathrm{AsS}_{4}+4.5 \mathrm{H}_{2} \mathrm{O}+3.75 \mathrm{O}_{2} \rightarrow \\
& \mathrm{C}_{5} \mathrm{H}_{7} \mathrm{O}_{2} \mathrm{~N}+3.0 \mathrm{CuSO}+\mathrm{H}_{3} \mathrm{AsO}_{4}+\mathrm{H}_{2} \mathrm{SO}_{4}
\end{aligned}
$$

In this case the oxygen and carbon dioxide cell yields are:

$$
\begin{aligned}
& \mathrm{Y}_{\mathrm{O}_{2}}=\frac{113}{3.75 \cdot 32}=0.94 \mathrm{~g} / \mathrm{g} \\
& \mathrm{Y}_{\mathrm{CO}_{2}}=\frac{113}{5 \cdot 44}=0.51 \mathrm{~g} / \mathrm{g}
\end{aligned}
$$

As could be expected, the carbon dioxide yield, related only with cell growth, is the same in the defined soluble medium and in the bioleaching of a mineral.

Equations [2], [3], [6], [7], [9] and [10] can be used to estimate the required mass transfer coefficients, as shown in Table 1. When not enough experimental data are available, the required coefficient for oxygen can be estimated from the stoichiometry equation of the main oxidation reaction. Oxygen transfer coefficients estimated by such method are included for chalcocite $\left(\mathrm{Cu}_{2} \mathrm{~S}\right)$, covellite $(\mathrm{CuS})$ and chalcopyrite $(\mathrm{CuFeS})$. The required ka's for oxygen are of the same order of magnitude or less than those that have been obtained experimentally in bioreactors (Acevedo et al. 1988; Liu 
et al. 1988; Boon and Heijen, 1998; Harvey et al. 1999; Rossi, 1999; Veljkovic et al. 1999). This implies that at the usual experimental conditions of 5 to $18 \% \mathrm{w} / \mathrm{v}$ pulp density, the process is not limited by oxygen supply. This situation may change at higher pulp densities (Bailey and Hansford, 1993; Hansford and Bailey, 1993; Loi et al. 1995).

Table 1. Required $k_{L}$ a values for the biooxidation of ferrous iron and an enargite gold concentrate ${ }^{a}$.

\begin{tabular}{lcc}
\hline & \multicolumn{2}{c}{$\mathbf{k}_{\mathbf{L}} \mathbf{a}, \mathbf{h}^{\mathbf{- 1}}$} \\
\cline { 2 - 3 } & $\mathbf{O}_{\mathbf{2}}$ & $\mathbf{C O}_{\mathbf{2}}$ \\
\hline Ferrous iron & 30 & 65 \\
Enargite & 3 & 84 \\
Chalcocite & 12 & - \\
Covellite & 20 & - \\
Chalcopyrite & 42 & - \\
\hline${ }^{2}$ Based on data by García (1997) and Acevedo et al. (1988).
\end{tabular}

In fermentation technology it is usual to correlate $\mathrm{k}_{\mathrm{Z}} \mathrm{a}$ with agitation power per unit volume and gas superficial velocity (Wang and Humphrey, 1968; Boon and Heijnen, 1998; Harvey et al. 1999):

$\mathrm{k}_{\mathrm{L}} \mathrm{a}_{\mathrm{O}}=\mathrm{K}\left(\frac{\mathrm{P}_{\mathrm{g}}}{\mathrm{V}}\right)^{\alpha} \cdot \mathrm{v}_{\mathrm{s}}^{\beta}$

In leaching bioreactors, the transfer coefficient may be influenced by the presence of solids (Mills et al. 1987), so the equations derived specifically for bioleaching are required. Table 2 shows some correlations of this type.

Because of its very low concentration in air, $0.03 \% \mathrm{v} / \mathrm{v}$, the equilibrium concentration of carbon dioxide is also very low, $0.00039 \mathrm{~g} / \mathrm{L}$ at $30^{\circ} \mathrm{C}$. The magnitude of the transfer potential, $\mathrm{C}^{*}-\mathrm{C}_{\mathrm{L}}$, is severely limited, leading to $\mathrm{CO}_{2}$ limited growth, as air flow rate is commonly determined based in the oxygen demand. Carbon dioxide limitation has been demonstrated by several authors (Torma et al. 1972; Norris, 1989; Boogard et al. 1990; Haddadin et al. 1993; Nagpal et al. 1993; Jensen and Webb, 1995; Jaworska and Urbanek, 1997; Acevedo et al. 1998; Boon and Heijen, 1998), but more work is required on this topic.

The $\mathrm{CO}_{2}$ transfer coefficient can be experimentally determined by a dynamic method on the exit gas (André et al. 1981) or estimated from de oxygen transfer coefficient (Liu et al. 1983; Nagpal et al. 1993):

$\mathrm{k}_{\mathrm{LC}_{\mathrm{C}}}=\mathrm{k}_{\mathrm{L}_{\mathrm{O}}}\left(\frac{\mathrm{D}_{\mathrm{O}}}{\mathrm{D}_{\mathrm{C}}}\right)^{-2 / 3}$

\section{Suspension of solids}

The CSTR is an ideal conception that implies a completely mixed content that presents no gradients, so the value of each variable is the same at every point within the liquid. That being the case, the exit stream has the same composition as the fluid within the reactor. As stated previously, tank bioleaching is a three-phase system composed by the incoming air and the outlet gas, the acidic aqueous liquor, and the microbial cells and mineral particles. The complex nature of this slurry makes the attainment of homogeneity especially difficult (Brucato and Brucato, 1998).

Agitation has a double purpose: to increase the rate of transfer operations, such as oxygen and carbon dioxide transfer and heat transfer, and to mix the reactor content. Under conditions of insufficient agitation the transfer operations may become limiting and the overall reaction performance will decline because of the appearance of zones of the fluid with insufficient nutrients or inadequate temperature or $\mathrm{pH}$ (Namdev et al. 1994). For several decades the use of disk turbines (or Rushton turbines) have been common in industrial fermentors.

Back in the fifties investigators were mainly looking for impellers that specifically enhanced oxygen transfer, but they neglected other important factors such as mixing, impeller gas flooding and power consumption, which are all negative assets for the disk turbine (Humphrey, 1998). The high shear stress exerted by the disk turbine on the fluid may also produce metabolic stress and cell growth inhibition (Toma et al. 1991). When mixing is specially important, axial flow impellers such as the hydrofoils become an advantageous alternative (Nienow, 1997; Junker et al. 1998; Myers and Bakker, 1998).

This is the case of bioleaching, where the oxygen demands are modest but the presence of fine solid particles impose an additional difficulty in obtaining homogeneous slurries. Table 3 lists the most commonly used type of impellers. It can be seen that the power required by disk turbines is very high compared with the requirements of other impellers. $N_{P}$, the power number, is a dimensionless number defined as $\mathrm{P} / \rho \cdot \mathrm{N}^{3} \mathrm{D}^{5}$.

Some of the hydrofoil designs developed in the mideighties (Lally, 1987) present convenient characteristics for their use in bioleaching reactors. Their power requirement is low, the mixing and solids suspension capabilities are good and oxygen and carbon dioxide transfer coefficients are comparable with those of the disk turbine (Kubera and Oldshue, 1992; Kaufman et al. 1997). 
Table 2. Correlations for the volumetric oxygen transfer coefficient in bioleaching processes.

\begin{tabular}{|c|c|c|}
\hline Correlation & Remarks & Reference \\
\hline $\mathrm{k}_{\mathrm{L}} \mathrm{a}_{\mathrm{O}}=\mathrm{K} \cdot\left(\frac{\mathrm{P}_{\mathrm{g}}}{\mathrm{V}}\right)^{0.93} \mathrm{v}_{\mathrm{s}}^{.0 .8}$ & $\begin{array}{l}\text { Stirred tank with ferrous ion as } \\
\text { energy source }\end{array}$ & $\begin{array}{l}\text { Gormely and Branion, } \\
1989\end{array}$ \\
\hline $\mathrm{k}_{\mathrm{L}} \mathrm{a}_{\mathrm{O}}=\mathrm{K} \cdot \rho^{-2.8} \mathrm{~N}^{2.65} \mathrm{v}_{\mathrm{s}}^{0.57}$ & $\begin{array}{l}20-\mathrm{L} \text { stirred tank. Model system with } \\
0.5 \text { to } 20 \% \mathrm{w} / \mathrm{v} \text { glass beads. The } \\
\text { density } \rho \text { of the suspension } \\
\text { accounts for the influence of the } \\
\text { solids }\end{array}$ & Liu et al. 1988 \\
\hline $\mathrm{k}_{\mathrm{L}} \mathrm{a}_{\mathrm{O}}=\mathrm{K} \cdot\left(\frac{\mathrm{P}_{\mathrm{g}}}{\mathrm{V}}\right)^{0.09} \mathrm{v}_{\mathrm{s}}^{1.13}$ & $\begin{array}{l}\text { 7-L stirred tank with } 15 \% \text { w/v } \\
\text { chalcopyrite concentrate and air } \\
\text { enriched with } 1 \% \mathrm{CO}_{2}\end{array}$ & Acevedo et al. 1988 \\
\hline $\mathrm{k}_{\mathrm{L}} \mathrm{a}_{\mathrm{O}}=\mathrm{K} \cdot\left(\frac{\mathrm{P}_{\mathrm{a}}}{\mathrm{V}}\right)^{0.33}$ & $\begin{array}{l}\text { 7-L Pachuca tank with } 15 \% \text { w/v } \\
\text { chalcopyrite concentrate and air } \\
\text { enriched with } 1 \% \mathrm{CO}_{2}\end{array}$ & Acevedo et al. 1988 \\
\hline $\mathrm{k}_{\mathrm{L}} \mathrm{a}_{\mathrm{O}}=(\mathrm{a}-\mathrm{b} \phi) \cdot\left(\frac{\mathrm{P}_{\mathrm{g}}}{\mathrm{V}}\right)^{0.67} \mathrm{v}_{\mathrm{s}}^{.0 .31}$ & $\begin{array}{l}18-\mathrm{L} \text { stirred tank, model system with } \\
0 \text { to } 40 \% \mathrm{w} / \mathrm{v} \text { solids }\end{array}$ & Mills et al. 1987 \\
\hline $\mathrm{k}_{\mathrm{L}} \mathrm{a}_{\mathrm{O}}=\mathrm{K} \cdot \mathrm{v}_{\mathrm{s}}^{(0.72-0.011 \phi)}$ & $\begin{array}{l}4-\mathrm{L} \text { air-lift column with } 0 \text { to } 24 \% \mathrm{w} / \mathrm{v} \\
\text { gold concentrate }\end{array}$ & Canales, 1999 \\
\hline $\mathrm{k}_{\mathrm{L}^{\mathrm{a}}} \mathrm{a}_{\mathrm{O}} \cdot \phi^{-0.0015} \mathrm{~F}^{2.8} \mathrm{~N}^{1.49}$ & $\begin{array}{l}14-\mathrm{L} \text { rotating drum reactor with } 50 \% \\
\text { w/w gold concentrate }\end{array}$ & Herrera et al. 1997 \\
\hline
\end{tabular}

Table 3. Impeller types used in bioreactors ${ }^{\mathrm{a}}$.

\begin{tabular}{lll}
\hline Impeller & Flow & $\mathbf{N}_{\mathbf{P}}$ \\
\hline Disk turbine & radial & 6.0 \\
Flat blade turbine & radial & 2.8 \\
Pitched blade turbine & axial & 1.2 \\
Curved blade turbine & radial & 2.8 \\
Hydrofoil & axial & 0.3 \\
Gas dispersing hydrofoil & axial & 0.8 \\
Marine helix & axial & 0.3 \\
Bar turbine & radial & 0.7 \\
\hline
\end{tabular}

Dickey and Fenic, 1976; Kubera and Oldshue, 1992.

The problem of solids suspension in agitated vessels has been addressed by several investigators. An important early work was that of Zwietering (1958), who studied the minimum required stirrer speed (referred afterwards as critical speed) and the stirrer dimensions for the complete suspension of solids. In this work the main objective was to avoid solids deposition on the bottom of the tank, but the homogeneity of the slurry was not of special concern. Different expressions for the critical speed have been proposed since then (Oldshue, 1983; Tatterson, 1996).
The concept of critical speed was developed for solid/liquid systems and does not consider the effect of bubble aeration. In this respect, some early work by Oldshue $(1969,1983)$ can be cited. This author points out that air bubbling has a negative effect in solids suspension and homogeneity, because the bubbles tend to disturb the flow pattern established by each type of impeller. In the specific field of tank bioleaching, Acevedo and Aroca (1986) present a comparative study of the effect of pulp density and aeration rate on the critical agitation speed when using three type of turbines: flat blade, curved blade and pitched blade. The critical speed increased with aeration and the pulp density showed a minor effect. The pitched blade turbine gave the lowest critical speeds, pointing to the fact that that the presence of an axial component in the flow is positive for solids suspension.

In the last few years a number of interesting papers have been published on agitation of slurries in bioreactors for the biooxidation of gold concentrates (Fraser, 1992; Kubera and Oldshue, 1992; Fraser, 1993; Oolman, 1993; Dew, 1995; Howk et al. 1995, Dew et al. 1997; Spencer et al. 1997; Greenhalgh and Ritchie, 1999; Harvey et al. 1999). 
Table 4. Large-scale plants for the biooxidation of refractory gold minerals ${ }^{\mathrm{a}}$.

\begin{tabular}{llll}
\hline \multicolumn{1}{c}{ Plant } & Start-up & Technology & Capacity \\
\hline Fairview, South Africa & 1986 & Tank leaching & 35 tons gold concentrate/day \\
Sao Bento, Brazil & 1990 & Tank leaching & 150 tons gold concentrate/day \\
Harbour Lights, Australia & 1992 & Tank leaching & 40 tons gold concentrate/day \\
Wiluna, Australia & 1993 & Tank leaching & 115 tons gold concentrate/day \\
Ashanti, Ghana & 1994 & Tank leaching & 1,000 tons gold concentrate/day \\
Youanmi, Australia & 1994 & Tank leaching & 120 tons gold concentrate/day \\
Sansu, Ghana & 1994 & Tank leaching & 1,000 tons gold concentrate/day \\
Tamboraque, Peru & 1999 & Tank leaching & 260,000 tons of zinc flotation tailings \\
Mount Leyshon, Australia & 1992 & Heap leaching & 1,370 tons of copper-gold ore/day \\
Newmont-Carlin, USA & 1995 & Heap leaching & 10,000 tons gold ore/day \\
\hline Brierley, 1997; Loayza and Ly, 1999. & & &
\end{tabular}

\section{Bioreactors and gold mining}

Gold is usually obtained from ores by solubilization with a cyanide solution and recovery of the metal from the solution. In ores known as refractory, small particles of gold are covered by insoluble sulfides.

These sulfides difficult the contact between cyanide and gold, resulting in low metal recoveries. In that case, a pre-treatment stage must be considered. Several alternative technologies are available, such as pressure oxidation, chemical oxidation, roasting and biooxidation, the latter currently being the alternative of choice.

In the biooxidation process, bacteria partially oxidize the sulfide coating covering the gold microparticles in ores and concentrates. Microorganisms belonging to the Thiobacillus and Leptospirillum genera are commonly used, although an increasing interest exists in thermophilic archeons (Dew et al. 1999; Howard and Crundwell, 1999). Gold recovery from refractory minerals can increase from $15-30 \%$ to $85-95 \%$ after biooxidation.

In the last 15 years several large-scale commercial gold processing units have been established. As shown in Table 4, most of them use stirred tank reactors to process flotation concentrates, although a few use heaps for low-grade ores and tailings.

For the reasons already discussed, the tank leaching plants listed in Table 4 uses several tanks connected in series. The Fairview plant operates with a total residence time of four days and a gold recovery of $94 \%$. The Sao Bento plant was originally designed for pressure oxidation. Nevertheless, a biooxidation reactor was added afterwards that allowed for a significant improvement in overall performance. The Ashanti plant has three biooxidation modules, each one consisting in six $900 \mathrm{~m}^{3}$ reactors (Dew et al. 1997).

The Youanmi plant consists in two $500 \mathrm{~m}^{3}$ tanks operated in parallel as a first stage, followed by a series of two $500 \mathrm{~m}^{3}$ tanks (Bell and Quan, 1999). Although the oldest plants were designed using disk turbine agitators, the newer ones use hydrofoil axial impellers, resulting in a better solids suspension and reduced power requirement (Dew et al. 1997).

\section{Future applications}

The future of bioreactors in mining appears promising. Gold biooxidation operations tend to increase in number and size in several countries the world over. The use of reactors will most probably extended to the bioleaching of other metals, such as copper. Currently studies are being carried on for the development of processes for the bioleaching of copper concentrates.

The experience gained in the heap leaching of copper and in the biooxidation of gold concentrates is being used in these studies. The bioleaching of chalcopyritic copper concentrates in the next few years will constitute a big breakthrough in biomining. The application of these technologies to the processing of nickel, zinc, and other heavy metals may also become a reality in the near future. 


\section{Nomenclature}

$\mathrm{a}, \mathrm{b}$ constants

$\mathrm{C}_{i} \quad$ equilibrium concentration of gas $\mathrm{i} g / \mathrm{L}$

$\mathrm{C}_{\mathrm{Li}}$ dissolved concentration of gas $\mathrm{i} \quad \mathrm{g} / \mathrm{L}$

$D_{C}$ diffusivity of carbon dioxide in $\mathrm{m}^{2} / \mathrm{s}$ water

CST continuous stirred tank reactor

$\mathrm{R}$

Do diffusivity of oxygen in water $\mathrm{m}^{2} / \mathrm{s}$

EW electrowinning

$F$ air flow $\mathrm{m}^{3} / \mathrm{s}$

K constant

$\mathrm{k}_{\mathrm{L}} \mathrm{a}_{\mathrm{C}} \quad$ volumetric carbon dioxide transfer $\mathrm{h}^{-1}$ coefficient

$\mathrm{k}_{\mathrm{L}} \mathrm{a}_{\mathrm{i}}$ volumetric mass transfer $\mathrm{h}^{-1}$

coefficient of gas i

$\mathrm{k}_{\mathrm{L}} \mathrm{a}_{\mathrm{O}}$ volumetric oxygen transfer $\mathrm{h}^{-1}$ coefficient

$\mathrm{k}_{\mathrm{LC}}$ carbon dioxide transfer coefficient $\mathrm{m} / \mathrm{s}$

kLO oxygen transfer coefficient $\mathrm{m} / \mathrm{s}$

$\mathrm{M}_{\mathrm{C}} \quad$ cell molecular mass

$\mathrm{M}_{\mathrm{CO} 2}$ carbon dioxide molecular mass

$\mathrm{M}_{\mathrm{O} 2}$ oxygen molecular mass

$\mathrm{N}$ impeller rotational speed $\mathrm{s}^{-1}$

$\mathrm{N}_{\mathrm{i}} \quad$ gas i demand $\mathrm{g} / \mathrm{L} \cdot \mathrm{h}$

$\mathrm{N}_{\mathrm{P}} \quad$ power number

$P \quad$ ungassed agitation pòwer W

$\mathrm{P}_{\mathrm{a}}$ aeration power W

$\mathrm{P}_{\mathrm{g}} \quad$ gassed agitation power $\quad \mathrm{W}$

PFR plug flow reactor

SE solvent extraction

$t$ Time $h$

$v_{\mathrm{s}} \quad$ superficial gas velocity $\mathrm{m} / \mathrm{s}$

$\mathrm{V}$ liquid volume $\mathrm{m}^{3}$

$\mathrm{X}$ cell concentration $\mathrm{g} / \mathrm{L}$

$\mathrm{Y}_{\mathrm{CO} 2}$ carbon dioxide cell yield $\mathrm{g} / \mathrm{g}$

$\mathrm{Y}_{\mathrm{i}} \quad$ cell yield of nutrient $\mathrm{i} \quad \mathrm{g} / \mathrm{g}$

$\mathrm{Y}_{\mathrm{O} 2}$ oxygen cell yield $\mathrm{g} / \mathrm{g}$

$\alpha, \beta \quad$ Exponents

$\phi \quad$ Pulp density

$\rho \quad$ Density of the slurry

$\mu \quad$ Specific growth rate

\section{References}

Acevedo, F., Canales, C. and Gentina, J.C. (1999). Biooxidation of an enargite-pyrite gold concentrate in aerated columns. In: Amils, R. and Ballester, A., eds. Biohydromatallurgy and the Environment Toward the Mining of the $21^{\text {st }}$ Century, Part A. Elsevier, Amsterdam, The Netherlands. pp. 301-308.

Acevedo, F., Gentina, J.C. and García, N. (1998). $\mathrm{CO}_{2}$ supply in the biooxidation of an enargite-pyrite gold concentrate. Biotechnology Letters 20:257-259.
Acevedo, F., Gentina, J.C. and Bustos, S. (1993). Bioleaching of minerals - a valid alternative for developing countries. Journal of Biotechnology 31:115123.

Acevedo, F. and Gentina, J.C. (1989). Process engineering aspects of the bioleaching of copper ores. Bioprocess Engineering 4:223-229.

Acevedo, F., Cacciuttolo, M.A. and Gentina, J.C. (1988). Comparative performance of stirred and Pachuca tanks in the bioleaching of a copper concentrate. In: Norris, P.R. and Kelly, D.P., eds. Biohydrometallurgy: Proceedings of the International Biohydrometallurgy Symposium, Warwick. Science and Technology Letters, Kew Surrey, U.K., $12^{\text {th }}-16^{\text {th }}$ July. pp. 385-394.

Acevedo, F. (1987). Mass balancing: an effective tool for fermentation process optimization. CRC Critical Reviews in Biotechnology 4:309-322.

Acevedo, F. and Aroca, G. (1986). Studies on the agitation and power characteristics of mineral slurries. In: Lawrence, R.W., Branion, R.M. and Ebner, H.G., eds. Fundamental and Applied Biohydrometallurgy. Elsevier, Amsterdam, The Netherlands. pp. 255-261.

Acharya, R. (1990). Bacterial leaching: a potential for developing countries. Genetic Engineering and Biotechnology Monitor 27:57-58.

Adamov, E.V., Po'lkin, S.I., Koreshkov, N.G. and Karavaiko, G.I. (1990). State of the art and prospects of bacterial tank leaching in the production of non-ferrous and rare metals. In: Karavaiko, G.I., Rossi, G. and Avakyan, Z.A., eds. International Seminar on Dump and Underground Bacterial Leaching Metals from Ores. Centre for International Projects-GKNT, Moscow, USSR, $1^{\text {st }}-6^{\text {th }}$ June. pp. 235-248.

André, G., Moo-Young, M. and Robinson, C.W. (1981). Improved method for the dynamic measurement of mass transfer coefficient for application to solid-substrate fermentation. Biotechnology and Bioengineering 23:1611-1622.

Atkins, A.S., Pooley, F.D. and Townsley, C.C. (1986). Comparative mineral sulphide leaching in shake flasks, percolation columns and pachuca reactors using Thiobacillus ferrooxidans. Process Biochemistry 21:310 .

Atkins, A.S. and Pooley, F.D. (1983). Comparison of bacterial reactors employed in the oxidation of sulphide concentrates. In: Rossi, G. and Torma, A.E., eds. Recent 
Progress in Biohydrometallurgy. Associazione Mineraria Sarda, Iglesias, Italy. pp. 111-125.

Avendaño, C. and Domic, E. (1994). Engineering design of LX-SX-EW plants. In: Wilkomirsky, I., Sánchez, M. and Hecker, C., eds. Chemical Metallurgy, Vol. II. Universidad de Concepción, Concepción, Chile. pp. 21-31.

Bailey, A.D. and Hansford, G.S. (1993). Factors affecting bio-oxidation of sulfide minerals at high concentration of solids: a review. Biotechnology and Bioengineering 42:1164-1174.

Barrette, L-M. and Couillard, D. (1993). Bacterial leaching of sulfide tailings in an airlift reactor. In: Torma, A.E., Wey, J.E. and Laksman, V.L., eds. Biohydrometallurgical Technologies, Vol.I. The Minerals, Metals and Materials Society, Warrendale, Pennsylavania, USA. pp. 205-215.

Bell, N. and Quan, L. (1999). The application of Bactech (Australia) Ltd. technology for processing refractory gold ores at Youanmi gold mine. In: IBS'97BIOMINE'97: Biotechnology comes of age. Conference Proceedings. Sydney, Australia, $4^{\text {th }}-6^{\text {th }}$ August. Paper M2.3.

Boogard, F.C., Kuenen, J.G., Heijen, J.J. and Van der Lans, R.G.J.M. (1990). Oxygen and carbon diooxide mass transfer and the aerobic, autotrophic cultivation of moderate and extreme thermophiles: a case study related to the microbial desulfurization of coal. Biotechnology and Bioengineering 35:1111-1119.

Boon, M. and Heijen, J.J. (1998). Gas-liquid mass transfer phenomena in bio-oxidation experiments of sulphide minerals: a critical review of literature data. Hydrometallurgy 48:187-204.

Brierley, J.A. and Brierley, C.L. (1999). Present and future commercial applications of biohydrometallurgy. In: Amils, R. and Ballester, A., eds. Biohydromatallurgy and the Environment Toward the Mining of the $21^{\text {st }}$ Century, Part A. Elsevier, Amsterdam, The Netherlands. pp. 81-89.

Brierley, C.L. (1997). Mining biotechnology: research to commercial development and beyond. In: Rawlings, D.E., ed. Biomining: Theory, Microbes and Industrial Processes. Springer Verlag, Berlin, Germany. pp. 3-17.

Brucato, A. and Brucato, V. (1998). Unsuspended mass of solid particles in stirred tanks. The Canadian Journal of Chemical Engineering 76:420-427.
Canales, C. (1999). Biooxidación de concentrados refractarios de oro en reactores de columna agitados por aire. Master's Thesis. Escuela de Ingeniería Bioquímica, Universidad Católica de Valparaíso, Valparaíso, Chile. pp. 81-86.

Canales, C., Acevedo, F. and Gentina, J.C. (1999). Biooxidación de Concentrados de oro a elevada densidad de pulpa: efecto de la suspensión de sólidos. In: Memorias IV Congreso Latinoamericano de Biotecnología, Vol.1. Huatulco, México, $12^{\text {th }}-17^{\text {th }}$ September. p. 150.

Dew, D.W., Van Buren, C., McEwan, K. and Bowker, C. (1999). Bioleaching base metal sulphide concentrates: a comparison of mesophile and thermophile bacterial cultures: In: Amils, R. and Ballester, A., eds. Biohydromatallurgy and the Environment Toward the Mining of the $21^{\text {st }}$ Century, Part A. Elsevier, Amsterdam, The Netherlands. pp. 229-238.

Dew, D.W., Lawson, E.N. and Broadhurst, J.L. (1997). The BIOX $^{\circledR}$ process for biooxidation of gold-bearing ores or concentrates. In: Rawlings, D.E., ed. Biomining: Theory, Microbes and Industrial Processes. Springer Verlag, Berlin, Germany. pp. 45-80.

Dew, D.H. (1995). Comparison of performance for continuous bio-oxidation of refractory gold ore flotation concentrates. In: Vargas, T., Jerez, C.A., Wiertz, J.V. and Toledo, H., eds. Biohydrometallurgical Processing, Vol.1. Universidad de Chile, Santiago, Chile. pp. 239251 .

Dickey, D.S. and Fenic, J.G. (1976). Dimensional analysis for fluid agitation systems. Chemical Engineering 83:139-145.

Fraser, G.M. (1993). Mixing and oxygen transfer in mineral bioleaching. Lightnin Technical Article $\mathrm{N}^{\circ}$ 177.00 .

Fraser, G. (1992). Gas dispersion and mixing for mineral oxidation reactors. In: Extractive Metallurgy of Gold and Base Metals. Conference Proceedings. Kalgoorlie, Australia, $26^{\text {th }}-28^{\text {th }}$ October. pp. 293-301.

García, N. (1997). Efecto del $\mathrm{CO}_{2}$ en la biooxidación de concentrados refractarios de oro de alto contenido de enargita. Master's Thesis. Escuela de Ingeniería Bioquímica, Universidad Católica de Valparaíso, Valparaíso, Chile. pp. 15, 92-96.

Gentina, J.C. and Acevedo, F. (1985). Microbial ore leaching in developing countries. Trends in Biotechnology 3:86-89. 
González, R., Gentina, J.C. and Acevedo, F. (1999). Modelo matemático y configuración óptima de un sistema continuo para la biooxidación de un mineral de oro refractario. In: Actas del XIII Congreso Nacional de Ingeniería Química, Antofagasta, 18 - 21 Octubre de 1998.

Gormely, L.S. and Brannion, R.M.R. (1989). Engineering design of microbiological leaching reactors. In: Biohydrometallurgy 1989: Proceedings of the International Biohydrometallurgy Symposium. Jackson Hole, Wyoming. $13^{\text {th }}-18^{\text {th }}$ August. pp. 499-518.

Greenhalgh, P. and Ritchie, I. (1999). Advancing reactor designs for the gold bioleaching process. In: Biomine '99: Conference Proceedings, Perth, Australia, $23^{\text {rd }}-24^{\text {th }}$ August. pp. 52-60.

Haddadin, J., Dagot, C. and Fick, M. (1993). Models of bacterial leaching. Enzyme and Microbial Technology 17:290-305.

Hansford, G.S. and Bailey, A.D. (1993). Oxygen transfer limitation of bio-oxidation at high solids concentration. In: Torma, A.E., Wey, J.E. and Laksman, V.L., eds. Biohydrometallurgical Technologies, Vol.I. The Minerals, Metals and Materials Society, Warrendale, Pennsylvania, USA. pp. 469-478.

Harvey, P.I., Batty, J.D., Dew, D.W. Slabbert, W. and Van Buuren C. (1999). Engineering considerations in bioleach reactor design. In: Biomine '99: Conference Proceedings. Perth, Australia, $23^{\text {th }}-24^{\text {th }}$ August. pp. 88-97.

Herrera, M.N., Escobar, B., Parra, N., González, C. and Vargas, T. (1997). Bioleaching of refractory gold concentrates at high pulp densities in a nonconventional rotating-drum reactor. In: The SME Annual Meeting. Denver, Colorado, USA, $24^{\text {th }}-27^{\text {th }}$ February. Preprint $\mathrm{N}^{\circ}$ 97-145.

Howard, D. and Crundwell, F.K. (1999). A kinetic study of the leaching of chalcopyrite with Sulfolobus metallicus. In: Amils, R. and Ballester, A., eds. Biohydromatallurgy and the Environment Toward the Mining of the $21^{\text {st }}$ Century, Part A. Elsevier, Amsterdam, The Netherlands. pp. 209-217.

Howk, R.A., Kelly, J.R. and Kubera, P.M. (1995). The effect of mixing impeller geometry and pumping direction on solids suspension homogeneity. Lightnin Technical Article $\mathrm{N}^{\mathrm{o}}$ 184.00.

Humphrey, A.E. (1998). Shake flask to fermentor: what have we learned? Biotechnology Progress 14:3-7.
Jaworska, M. and Urbanek, A. (1997). The influence of carbon dioxide concentration in liquid medium on elemental sulphur oxidation by Thiobacillus ferrooxidans. Bioprocess Engineering 16:361-365.

Jensen, A.B. and Webb, C. (1995). Ferrous sulphate oxidation using Thiobacillus ferrooxidans: a review. Process Biochemistry 30:225-236.

Junker, B.H., Stanik, M., Barna, C., Salmon, P. and Buckland, B.C. (1998). Influence of impeller type on mass transfer in fermentation vessels. Bioprocess Engineering 19:403-413.

Karavaiko, G.I. (1985). Microbiological Processes for the Leaching of Metals from Ores: State-of-the-Art Review. Centre for International Projects-GKNT, Moscow, USSR. 69 p.

Kaufman, P., Kubera, P. and Post, T. (1997). Fermentation: critical process phenomena and new technology developments that affect yield and productivity. Pharmaceutical Engineering 17:1-6.

Kelley, B.C. and Tuovinen, O.H. (1988). Microbiological oxidation of minerals in tailings. In: Salomons, W. and Foerstner, U., eds. Chemistry and Biology of Solid Waste: Dregded Material and Mine Tailings. Springer-Verlag, New York, USA. pp. 33-53.

Kubera, P.M. and Oldshue, J.Y. (1992). Advanced impeller technologies match mixing performance to process needs. Lightnin Technical Article 171.00

Lally, K.S. (1987). A-315 axial flow impeller for gas dispersion. Lightnin Technical Article 144.00.

Lawrence, R.W. and Poulin, R. (1995). The demand for biotechnology in mining in the $21^{\text {st }}$ century. In: Vargas, T., Jerez, C.A., Wiertz, J.V. and Toledo, H., eds. Biohydrometallurgical Processing, Vol.1. Universidad de Chile, Santiago, Chile. pp. 185-195.

Levenspiel, O. (1972). Chemical Reaction Engineering. $2^{\text {nd }}$ Edition. J. Wiley and Sons, New York, USA. 578 p.

Liu, M.S., Brannion, R.M.R. and Duncan, D.W. (1988). Oxygen transfer to Thiobacillus cultures. In: Norris, P.R. and Kelly, D.P., eds. Biohydrometallurgy: Proceedings of the International Biohydrometallurgy Symposium, Warwick. Science and Technology Letters, Kew Surrey, U.K. $12^{\text {th }}-16^{\text {th }}$ July. pp. $375-384$.

Liu, M.S, Branion, R.M.R. and Duncan, D.W. (1983). Effects of ferrous iron, dissolved oxygen, and inert solidas concentrations on the growth of Thiobacillus 
ferrooxidans. The Canadian Journal of Chemical Engineering 66:445-451.

Loi, G., Trois, P. and Rossi, G. (1995). Biorotor ${ }^{\circledR}$ : a new development for biohydrometallurgical processing. In: Vargas, T., Jerez, C.A., Wiertz, J.V. and Toledo, H., eds. Biohydrometallurgical Processing, Vol.1. Universidad de Chile, Santiago, Chile. pp. 263-271.

Loayza, C. and Ly, M.E. (1999). Biooxidation of arsenopyrite concentrate for industrial plant Tamboraque using acid mine drainage. In: Biomine' 99: Conference Proceedings. Perth, Australia, $23^{\text {rd }}-25^{\text {th }}$ August, pp. 162-167.

Mills, D.B., Bar, R. and Kirwan, D.J. (1987). Effect of solids on oxygen transfer in agitated three-phase systems. American Institute of Chemical Engineering Journal 33:1542-1549.

Monod, J. (1949). The growth of bacterial cultures. Annual Reviews in Microbiology 3:371-394.

Montealegre, R., Bustos, S., Rojas, J., Neuburg, H., Araya, C., Yáñez, H., Tapia, R. and Rauld. J. (1993). Application of the bacterial thin layer process to Quebrada Blanca ores. In: Torma, A.E., Wey, J.E. and Laksman, V.L., eds. Biohydrometallurgical Technologies, Vol.I. The Minerals, Metals and Materials Society, Warrendale, Pennsylvania, USA. pp. $1-14$.

Myers, K.J. and Bakker, A. (1998). Solids suspension with up-pumping pitched-blade high-efficiency impellers. Canadian Journal of Chemical Engineering 76:433-440.

Nagpal, S., Dahistrom, D. and Oolman, T. (1993). Effect of carbon dioxide concentration on the bioleaching of a pyrite-arsenopyrite ore concentrate. Biotechnology and Bioengineering 41:459-464.

Namdev, P.K., Dunlop, E.H., Wenger, K. and Villeneuve, P. (1994). Role of turbulence in fermentations. In: Galindo, E. and Ramírez, O.T., eds. Advances in Bioprocess Engineering. Kluwer Academic Publishers, Dordrecht, The Netherlands. pp. 149-156.

Nedeltchev, S., Ookawara, S. and Ogawa, K. (1999). A fundamental approach to bubble column scale-up based on quality of mixedness. Journal of Chemical Engineering of Japan 32:431-439.

Nienow, A.W. (1997). A status review of mixing in bioreactors. In: Engineering Foundation Conference on Biochemical Engineering X . Kananaskis, Canada, $18^{\text {th }}-23^{\text {rd }}$ May. Available on the Web: http://hugroup.cems.umn.edu/Archive.htm

Nikolov, L., Mehochev,D. and Dimitrov, D. (1986). Continuous bacterial ferrous iron oxidation by Thiobacillus ferrooxidans in rotating biological contactors. Biotechnology Letters 8:707-710.

Norris, P.R. (1989). Factors affecting bacterial mineral oxidation: the example of carbon dioxide in the context of bacterial diversity. In: Biohydrometallurgy: Proceedings of the International Biohydrometallurgical Symposium. Jakson Hole, Wyoming, $13^{\text {th }}-18^{\text {th }}$ August. pp.3-14.

Oolman, T. (1993). Bioreactor design and scaleup applications in mineral bioleaching. In: Torma, A.E., Wey, J.E. and Laksman, V.L., eds. Biohydrometallurgical Technologies, Vol.I. The Minerals, Metals and Materials Society, Warrendale, Pennsylvania, USA. pp. 401-415.

Oldshue, J.Y. (1983). Fluid Mixing Technology. McGraw-Hill Publications C., New York, N.Y., USA. $574 \mathrm{p}$.

Oldshue, J.Y. (1969). Suspending solids and dipersing gases in mixing vessel. Industrial and Engineering Chemistry 61:79-89.

Pinches, A., Chapman, J.T., Te Riele, W.A.M. and Van Staden, M. (1988). The performance of bacterial leach reactors for the pre-oxidation of refractory gold-bearing sulphide concentrates. In: Norris, P.R. and Kelly, D.P., eds. Biohydrometallurgy: Proceedings of the International Biohydrometallurgy Symposium, Warwick. Science and Technology Letters, Kew Surrey, U.K. $12^{\text {th }}-16^{\text {th }}$ July. pp. 329-344.

Rawlings, D.E., ed. (1997). Biomining: Theory, Microbes and Industrial Processes. Springer Verlag, Berlin, Germany. 302 p.

Readett, D.J. (1999). Heap leaching. In: Biomine '99: Conference Proceedings, Perth, Australia. $23^{\text {rd }}-24^{\text {th }}$ August. pp.61-80.

Rossi, G. (1999). The design of bioreactors. In: Amils, R. and Ballester, A., eds. Biohydromatallurgy and the Environment Toward the Mining of the $21^{\text {st }}$ Century, Part A. Elsevier, Amsterdam, The Netherlands. pp. 6180 .

Spencer, P.A., Satalic, D.M., Baxter, K.G., and Pinches, T. (1997). Key aspects in the design of a bacterial oxidation reactor. In: IBS'97-BIOMINE'97: 
Biotechnology comes of age. Conference Proceedings. Sydney, Australia, $4^{\text {th }}-6^{\text {th }}$ August. Paper M14.1.

Tatterson, G.B. (1996). Scaleup and Design of Industrial Mixing Processes. McGraw-Hill, Inc., New York, New York, USA. pp. 107-201.

Toma, M.K., Ruklisha, M.P., Vanags, J.J., Zeltina, M.O., Leite, M.P., Galinina, N.I., Viesturs, U.E. and Tengerdy, R.P. (1991). Inhibition of microbial growth and metabolism by excess turbulence. Biotechnology and Bioengineering 38:552-556.

Torma, A.E. (1977). The role of Thiobacillus ferrooxidans in hydrometallurgical processes. Avances in Biochemical Engineering 6:1-37.

Torma, A.E., Walden, C.C., Duncan, D.W. and Branion, R.M.R. (1972). The effect of carbon dioxide and particle surface area on the microbiological leaching of a zinc sulfide concentrate. Biotechnology and Bioengineering 14:777-786.

Veljkovic, V.B., Savic, D.S., Lazic, M.L. and Vrvic, M.M. (1999). Oxygen mass transfer requirements during ferrous iron oxidation by Thiobacillus ferrooxidans under controlled $\mathrm{pH}$ conditions. In: Amils, R. and Ballester, A., eds. Biohydromatallurgy and the Environment Toward the Mining of the $21^{\text {st }}$ Century, Part A. Elsevier, Amsterdam, The Netherlands. pp. 617-623.

Wang, D.I-C. and Humphrey, A.E. (1968). Developments in agitation and aeration of fermentation systems. Progress in Industrial Microbiology 8:1-33.

Zwietering, T.N. (1958). Suspending of solid particles in liquid by agitators. Chemical Engineering Science $8: 244-253$ 